\title{
PEMBIASAAN SPIRITUAL UNTUK MENINGKATKAN PENDIDIKAN KARAKTER PESERTA DIDIK
}

\section{SPIRITUAL HABITUATION TO IMPROVE CHARACTER EDUCATION OF STUDENTS}

\author{
ZK Lathifah'ia dan RK Rusli ${ }^{1}$ \\ 1 Program Studi Manajemen Pendidikan Islam, Fakultas Keguruan dan Ilmu Pendidikan, \\ Universitas Djuanda Bogor, Jl. Tol Ciawi No. 1 Kotak Pos 35 Ciawi Bogor 16720 \\ a Korespondensi: Zahra Khusnul Lathifah, Email: zahra.khusnul.lathifah@unida.ac.id \\ (Diterima: 08-01-2019; Ditelaah: 15-01-2019; Disetujui: 16-02-2019)
}

\begin{abstract}
Government programs in strengthening character education in schools through the integration of 2013 curriculum learning need to be fully supported by positive efforts by both the community and educational institutions as legal institutions that overshadow the education process as a whole. The aim of study was to find out how the role of spiritual habituation in Cicurug Elementary School 3 District Cicurug Bogor Regency towards the character development of students. The research was done in descriptive qualitative research type through naturalistic approach, because research is carried out with real conditions. Data was collected through some methods such as observation, interviews and documentation. The results revealed that spiritual habituation programs were carried out at Cicurug Elementary School 3 through a series of activities such as; taushiah, recitation of prayers before teaching and learning activities, reading / memorizing short surah of alQur'an, habituation of 3S (Smiling, Saying hello, Saying Salam), performing Dzuhur prayer in congregation, scheduling Dhuha prayer and infaq activities, can improve the quality of student's character in this school. Some points that can be summarized as the results of this research are: 1) spiritual habituation in Cicurug Elementary School 3 is carried out through a series of programs integrated in the process of learning, 2) with habituation methods, students carry out all religious activities with voluntary feelings without compulsion , 3) spiritual habituation is direct learning (experiential-learning), 4) habituation methods prove to be the most effective method compared to several other methods in teaching religious values to students, 5) spiritual habituation can increase the awareness of students and teachers in developing a commendable, religious, honest, independent, responsible, disciplined, tolerant, peaceful and caring social attitude.
\end{abstract}

Keywords: character education, habituation method, spiritual activities.

\begin{abstract}
ABSTRAK
Program pemerintah dalam penguatan pendidikan karakter melalui sekolah, perlu didukung sepenuhnya dengan upaya-upaya positif baik oleh masyarakat maupun institusi pendidikan sebagai lembaga legal yang menaungi proses pendidikan dan pembelajaran secara menyeluruh. Penelitian yang bertujuan untuk mengetahui bagaimana peranan pembiasaan spiritual terhadap pengembangan pendidikan karakter peserta didik ini dilaksanakan di SD Negeri 3 Cicurug Kabupaten Bogor. Dengan menggunakan jenis penelitian kualitatif deskriptif melalui pendekatan naturalistik, latar penelitian diambil dengan kondisi yang sesungguhnya (natural setting). Pengumpulan data dilakukan oleh peneliti dengan mengobservasi subyek dan obyek penelitian, melakukan wawancara serta mengambil beberapa dokumentasi yang diperlukan. Hasil penelitian mengungkapkan bahwa program pembiasaan spiritual yang dilaksanakan di SD Negeri 3 Cicurug melalui serangkaian kegiatan
\end{abstract}


seperti; taushiah, pembacaan do'a sebelum pembelajaran dimulai di kelas, pembacaan/hafalan surat-surat pendek, pembiasaan 3S (Senyum, Sapa, Salam), pelaksanaan sholat Dzuhur berjama'ah, penjadwalan sholat Dhuha dan kegiatan infaq, dapat meningkatkan tingkat mutu pelaksanaan pendidikan karakter pada peserta didik di sekolah ini. Beberapa poin yang dapat dirangkum sebagai hasil penelitian ini, adalah: 1) pembiasaan spiritual di SD Negeri 3 Cicurug dilaksanakan melalui serangkaian program yang diintegrasikan ke dalam proses pendidikan dalam keseharian peserta didik di sekolah, 2) dengan metode pembiasaan, peserta didik melaksanakan seluruh kegiatan keagamaan dengan rasa sukarela tanpa keterpaksaan, 3) pembiasaan spiritual merupakan pembelajaran secara langsung (experiential-learning), 4) metode pembiasaan terbukti menjadi metode yang efektif jika dibandingkan dengan beberapa metode lain dalam mengajarkan nilai-nilai keagamaan terhadap peserta didik, 5) pembiasaan spiritual juga dapat membantu peserta didik dan guru dalam mengembangkan sikap terpuji, religius, jujur, mandiri, bertanggungjawab, disiplin, bersikap toleran, mencintai kedamaian dan memiliki sifat peduli sosial.

Kata Kunci: metode pembiasaan, kegiatan spiritual, pendidikan karakter.

Lathifah, Z. K., \& Rusli, R. K. (2019). Pembiasaan Spiritual untuk Meningkatkan Pendidikan Karakter Peserta Didik. Tadbir Muwahhid, 3(1), 14-26.

\section{PENDAHULUAN}

Dewasa ini dunia pendidikan mengalami banyak sekali problematika yang berhubungan dengan sikap maupun karakter anak. Hal inilah yang harus menjadi perhatian besar bagi semua pihak, terutama orang tua dalam mengasuh anakanaknya, tenaga pendidik, dan lingkungan masyarakat. Menurut UU RI Nomor 20 Tahun 2003 tentang Sistem Pendidikan Nasional. Pendidikan tidak hanya terfokus kepada hal kognitif saja peningkatan akhlak pun sangat dijunjung tinggi yang direalisasikan secara konseptual dalam kehidupan. Terwujudnya pencapaian pendidikan karakter di lingkungan sekolah menjadi gerbang utama menuju terciptanya generasi muda yang berilmu pengetahuan tinggi, bertaqwa kepada Allah SWT, berkepribadian cakap, mandiri, kreatif, bersikap demokratis dan bertanggungjawab sebagai warga Negara yang mampu bersikap baik dan memberikan contoh baik bagi yang lain.(Ainiyah, 2013)
Sekolah Dasar Negeri 3 Cicurug menjadi sekolah yang cukup diminati di lingkungan kecamatan Cicurug. Namun begitu, dari hasil observasi peneliti mendapatkan beberapa data terkait pelanggaran etika oleh peserta didik, diantaranya; berkata kasar, membully teman dari sisi fisik dan psikis walaupun masih dalam kategori ringan, dan kurangnya kedisiplinan dalam mengikuti berbagai kegiatan.

Maka dari itu penting adanya sebuah character building di dalam institusi sekolah untuk membangun stabilitas kemajuan bangsa yang tangguh, mandiri, dan berkarakter tunggal. Dalam konteks lembaga pendidikan, keutamaan akademis atau keutamaan yang mendukung bagi tercapainya keutamaan intelektual adalah ciri lembaga pendidikan. Misi utama pendidikan adalah melakukan pengembangan terhadap potensi peserta didik sebagai pembelajar yang baik. Larry Nucci dkk. (2014) dalam bukunya Hand Book of Moral and Character Education menyatakan bahwa dalam perspektif perkembangan disiplin, anak didik perlu 
diberikan pengondisian suasana tentang pentingnya kepedulian, saling menyayangi, saling menghargai dan bekerjasama ketika berada dalam lingkungan sekolah, sehingga mereka dapat membangun sebuah cara pandang bahwa berkarakter baik dan memiliki kepedulian terhadap orang lain bukan hanya dikembangkan di dalam rumah atau keluarga saja tetapi dimanapun mereka bersosialisasi termasuk di sekolah.

Pengembangan karakter dilaksanakan dengan cara pembiasaan terjadwal ataupun tidak terjadwal dan pelaksanaannya pun boleh dilakukan di dalam ataupun diluar kelas. Pembiasaan spiritual di sekolah termasuk diantaranya kegiatan yang dilaksanakan dengan teratur atau terus menerus yang bertujuan membiasakan peserta didik agar melakukan hal yang baik. Pembiasaan dapat diibaratkan sebagai salah satu metode pendidikan yang diperlukan dalam upaya pembentukan karakter. Misalnya, kebiasaan baik yang diupayakan penerapannya dalam lingkungan terdekat seperti keluarga, oleh orang tua kepada anak tanpa intervensi. Jika pembiasaan seperti ini dilakukan secara kontinyu, tentu akan membuat nilai-nilai baik tertanam pada diri anak tanpa diiringi dengan rasa keterpaksaan. Pembiasaan seperti ini secara perlahan akan mengkristal dan mendarah daging dalam dirinya sehingga tercermin dalam karakter dan kepribadiannya (Nucci et al., 2014).

Yaumi dalam Kadek memaknai karakter religius sebagai sebuah sikap ataupun perilaku penuh kepatuhan, dimana manusia sebagai pelakunya, dalam melaksanakan ajaran agama yang diyakininya, bertoleransi terhadap umat lain serta hidup rukun berdampingan. Agama atau religi mempunyai kaitan erat dengan aspek moral serta etika dalam penerapan nilai-nilainya. Pendidikan karakter yang menyatu dalam proses pembelajaran menjadi sebuah kombinasi baik yang tidak saling berlawanan. (Kadek et al., 2017).

Karakter religius akan terbentuk melalui sebuah pembiasaan dalam spirit keagamaan atau spiritual. Menelaah tentang spiritual dalam Islam, Taufiq Pasiak dalam Rahmawati (2016) mendefinisikan makna spiritual sebagaimana asal kata bahasa Arabnya (ruhaniyah) sebagai sebuah ruh yang tidak lepas dengan aspek Ketuhanan yang berarti bahwa berbicara tentang spiritualitas sama artinya dengan membicarakan Tuhan (Allah SWT). Definisi pendidikan sebagaimana tersurat dalam Undang-Undang Sisdiknas No. 20 Tahun 2003 Pasal 1 juga mengisyaratkan tentang pengembangan kekuatan spiritual keagamaan. Untuk itu, melalui kegiatan keagamaan secara bersama-sama di sekolah, diharapkan agar peserta didik dapat mengembangkan kekuatan spiritual yang dapat membentuk karakter baik yang menginternalisasi kedalam dirinya. Para pakar pendidikan anak bersepakat bahwa metode terbaik dan dirasa sangat efektif untuk menumbuhkan keimanan dan akhlak terpuji pada anak adalah melalui penerapan kebiasaan dan kedisiplinan (Patmonodewo \& Kebudayaan, 2000).

Depiyanti (2014) dalam penelitiannya tentang Model Pendidikan Karakter pada Islamic Full Day School di SD Cendekia Leadership School Bandung mengemukakan satu temuan bahwa metode yang diimplementasikan dalam pembangunan karakter terhadap siswa di sekolah ini, yang dirasakan telah memberikan input yang positif adalah metode pengalaman langsung atau metode pembiasaan, dimana peserta didik diajarkan untuk merasakan secara langsung apa yang dialami dan mengambil manfaat dari kebiasaan-kebiasaan baik yang 
dilakukan secara bersama-sama dan berterusan.

Abdullah Nashih Ulwan (2012), seorang pakar pendidikan anak mengemukakan tentang fitrah lahir yang dipunyai setiap anak yaitu kecenderungan, kesadaran dalam beragama dan ketauhidan yang murni. Bagaimana anak kemudian akan dapat mengembangkan kecenderungan dan potensinya untuk menjadi seseorang dengan pribadi yang lebih baik, sangat tergantung dari pembiasaan dan pendidikan yang ia dapatkan dari hasil pendidikan orang tuanya maupun orang-orang terdekatnya.

Metode pembiasaan terbukti efektif untuk menerapkan nilai positif bagi anak hingga tumbuh dan berkembang menjadi sebuah pembiasaan yang juga bernilai kebaikan. Untuk itu, dalam sebuah institusi pendidikan, diperlukan adanya sebuah pengondisian lingkungan melalui berbagai kegiatan positif yang dapat mendukung anak untuk mengenali Tuhan-nya, mengenali dirinya sendiri dan temantemannya, serta mengenali alam sekitar sebagai bukti adanya Sang Khaliq.

Pendidikan bermakna penyampaian ilmu/ pengetahuan (transferring of knowledge) dari seorang pendidik atau guru kepada siswanya di dalam kelas, sebagai sebuah proses interaksi yang disebut pembelajaran. Zaini dkk (2013) mengartikan pendidikan dengan makna luas dan mendalam sebagaimana pernyataannya bahwa pendidikan merupakan proses pengembangan karakter dan norma anak didik secara menyeluruh. Karena guru memberikan bukan hanya pemahaman dalam proses belajar mengajar namun juga penghayatan dan pengamalan yang mengakar pada diri peserta didik sehingga dapat membuatnya menjadi pribadi yang lebih baik.
Aziz sebagaimana yang dikutip Depiyanti (2014) dalam ulasannya mendefinisikan arti kata karakter sebagai sebuah kualitas moral yang membedakan masing-masing individu. Karakter yang baik tidak akan terbentuk begitu saja tetapi harus dibentuk dan dikembangkan melalui proses pendidikan yang dinamakan pendidikan karakter. Untuk itu, sekolah dipandang sebagai lingkungan yang cukup kondusif untuk mengembangkan pendidikan dengan unsurunsur karakter yang terintegrasi dalam pembelajaran.

Undang-Undang No. 20 Tahun 2003 tentang Sistem Pendidikan Nasional juga sarat dengan pendidikan karakter, dimana disebutkan bahwa pendidikan nasional berfungsi untuk mengembangkan kompetensi dan watak kepribadian bagi peradaban bangsa yang memiliki integritas dalam upaya meningkatkan kualitas hidup bangsa melalui peningkatan kompetensi dan potensi generasi muda pembelajar menjadi manusia yang beriman, bertaqwa kepada Allah SWT, mempunyai akhlak yang mulia, berbadan sehat, berilmu pengetahuan luas, memiliki kecakapan dan daya kreatifitas yang tinggi, kemandirian dan mampu menjadi warga Negara yang menjunjung tinggi sikap demokratis serta bertanggungjawab terhadap nilai-nilai Pancasila.

Definisi lain menyatakan pendidikan karakter merupakan sebuah teknik pembangunan nilai karakter dalam sebuah komunitas institusi pendidikan (sekolah) yang mencakup pengetahuan, kesadaran/kemauan untuk berbuat dan bertindak mengimplementasikan nilai-nilai yang telah disepakati bersama. Pendidikan karakter juga dapat didefinisikan sebagai sebuah upaya untuk mengaktifkan seluruh dimensi dan aspek dalam sebuah lembaga pendidikan untuk mendorong tumbuhnya 
kesadaran untuk membangun karakter baik secara optimal (Sukardi, 2016). Muslich (2011) menyatakan pendapat yang senada bahwa pendidikan pekerti luhur, dimana didalamnya melibatkan beberapa aspek antara lain teori pengetahuan, perasaan, juga tindakan. Dalam teori ini dia mencoba untuk menjabarkan pendapat Lickona yang memperjelas kedudukan ketiga unsur itu dalam pelaksanaannya, harus dilakukan dengan sistematis dan simultan supaya pendidikan karakter berjalan dengan efektif. Dengan pendidikan karakter, anak dapat mengasah kecerdasan emosinya.

Dalam perspektif Islam, kajian pendidikan karakter terlihat jelas dalam beberapa ayat dalam surah al-Luqman, salah satu diantaranya sebagaimana tertera pada ayat 17 , yang artinya:

"Hai anakku, dirikanlah shalat dan suruhlah (manusia) mengerjakan yang baik dan cegahlah (mereka) dari perbuatan yang mungkar dan bersabarlah terhadap apa yang menimpa kamu. Sesungguhnya yang demikian itu termasuk hal-hal yang diwajibkan (oleh Allah)" (al-Luqman: 17).

Ayat-ayat diatas memberikan pernyataan yang jelas bagaimana Islam memandang karakter sebagai hal yang sangat penting dan mendasar, yang dijadikan sebagai falsafah hidup seorang muslim dalam kerangka ketaatannya kepada Sang Khaliq. Bahkan jika menilik sejarah bagaimana diutusnya seorang manusia mulia Rasulullah SAW ke muka bumi ini juga tidak lain untuk tujuan utama yakni, untuk menyempurnakan akhlaq manusia (liutammima makaarimal akhlaq).

Menurut Berkowitz et. al. (2017), tujuan sesungguhnya dari pendidikan karakter adalah menjadikan anak maupun remaja kelak menjadi orang yang baik, mengembangkan hal-hal yang baik dan melakukan yang terbaik. Sehingga bisa dikatakan bahwa anak yang berkarakter baik akan menjadi seorang agen kebaikan, yang bukan hanya berperilaku baik namun juga menjadikan dirinya sebagai seorang role model bagi yang lainnya.

Sebagaimana yang dikutip oleh Mumpuni (2018), Lickona berpendapat bahwa strategi jitu untuk mengembangkan pendidikan karakter pada usia sekolah dasar 7-12 tahun yaitu melalui metode contoh. Dengan saling mencontohkan antara satu dengan yang lain, dan melakukan kebiasaan-kebiasaan baik secara bersama-sama, penanaman pendidikan karakter di sekolah dapat tercipta dengan baik.

Integrasi pendidikan karakter dengan kurikulum sekolah, memiliki arti bahwa pendidikan karakter akan mengantarkan seorang anak memiliki kualitas iman, ketaqwaan, dan keikhlasan yang lebih baik sehingga dapat tercapai tujuan pembangunan nasional yang menginginkan terciptanya generasi-generasi bangsa yang berakhlaq mulia, memiliki moral dan adab yang baik, serta berpegang teguh pada falsafah dasar Pancasila (Khotimah \& Manajemen Pendidikan Karakter, 2016).

Dengan demikian, dapat disimpulkan bahwa pendidikan karakter adalah sebuah proses pembekalan yang melatih potensi anak secara sistematis dan berkesinambungan yang didapukan dengan dasar-dasar keagamaan, kegiatan yang dilakukan ialah secara nyata untuk membentuk kebiasaan anak sejak dini agar kualitas anak dalam mengambil keputusan, berkomunikasi, peka terhadap lingkungan, bersikap baik kepada makhluk-Nya menjadi bijaksana dan jauh lebih baik lagi sehingga menghasilkan generasi muda yang cerdas, jujur, santun, dermawan, dan religius.

Salah satu model pendidikan karakter yang dirumuskan oleh Majid \& Andayani dan dikutip oleh Aeni (2016) yaitu model 
TADZKIRAH (baca: tadzkiroh) yang dalam bahasa Arab bermakna peringatan. Masingmasing huruf dalam kata TADZKIROH memiliki arti khusus, yaitu Tunjukkan teladan, Arahkan (berikan bimbingan), Dorong (beri motivasi), Zakiyyah (bersih/murni), Kontinuitas (pembiasaan), Ingatkan, Repetisi/ Refleksikan, Organisasikan dan Heart (hati). Dalam kaitannya dengan pengembangan pendidikan karakter di sekolah dasar, model seperti ini dianggap sesuai dengan karakteristik peserta didik. Guru memberikan teladan, arahan, motivasi dan mengingatkan dengan hati bersih, mengatur pembiasaan-pembiasaan baik untuk dapat berjalan, sehingga pencapaian character building di sekolah dapat berjalan sebagaimana yang diharapkan. Peserta didik melakukan segala aktifitas, yang mendukung pengembangan kualitas spiritualnya tanpa keterpaksaan, namun dari hati (heart), dengan kesadaran diri sehingga berkarakter baik bukan hanya menjadi kewajiban etika di dalam lingkungan sekolah namun menjadi kebiasaan yang melekat dimanapun mereka berada.

\section{METODE}

\section{Jenis Penelitian}

Nasution dalam Rukajat mengemukakan bahwa penelitian kualitatif, secara hakikat, merupakan penelitian yang dilakukan untuk mengamati perilaku orang disekitar, melakukan interaksi dengan mereka dan mencoba untuk membaca serta menafsirkan apa yang terjadi dalam bentuk kalimat ataupun kata-kata. Dalam penelitian kualitatif, ohjek yang diteliti merupakan sebuah permasalahan yang telah dialami dan dijadikan sebagai target penelitian contohnya yaitu tentang perilaku, persepsi, motivasi, tindakan dan lain-lain.

Peneliti menggunakan jenis penelitian kualitatif, dikarenakan metode ini dianggap paling sesuai dengan konteks penelitian yang sedang peneliti lakukan, yaitu memberikan deskripsi tentang perilaku peserta didik dalam pembiasaan spiritual yang dilaksanakan di SD Negeri 3 Cicurug dalam upaya penanaman nilai-nilai karakter. Frankel dalam Anggito (2018) menyatakan prosedur penelitian pada penelitian jenis ini akan menghasilkan data deskriptif berupa pernyataan-pernyataan tertulis maupun secara lisan yang didapatkan dari orang-orang maupun perilaku yang dapat diamati. Penelitian kualitatif lebih mementingkan sisi proses daripada hasil. Data yang dikumpulkan berupa kata-kata, gambar maupun perilaku tidak disajikan dalam bentuk angka statistik, tetapi tersaji dalam bentuk kualitatif. Adapun jenis pendekatan yang digunakan adalah pendekatan naturalistik yang berarti bahwa penelitian dilakukan dengan memakai latar yang sesungguhnya (natural setting).

\section{Waktu dan Tempat Penelitian}

Penelitian dilakukan dalam kurun waktu tiga bulan yaitu pada bulan November 2018 - Januari 2019. Penelitian berlokasi di SD Negeri 3 Cicurug Kecamatan Cicurug Kabupaten Sukabumi, dengan pertimbangan bahwa sekolah tersebut mendukung untuk diteliti karena peneliti menjumpai adanya pembiasaan spiritual dalam pendidikan karakter pada peserta didik. Selain itu, penelitian sejenis juga belum pernah dilakukan di sekolah ini.

Untuk menggali informasi dan data-data yang diperlukan, kepala sekolah, guru maupun peserta didik di SD Negeri 3 Cicurug dijadikan sebagai subjek penelitian. 
Adapun objek yang akan diteliti adalah pembiasaan spiritual dalam meningkatkan pendidikan karakter pada peserta didik di SD Negeri 3 Cicurug Kecamatan Cicurug Kabupaten Sukabumi.

\section{Prosedur Penelitian}

Penelitian dilakukan dengan melakukan observasi langsung, wawancara dengan narasumber maupun dokumentasi; baik berupa data maupun foto untuk mendukung data yang didapatkan dari hasil observasi lapangan dan wawancara. Dengan metode kualitatif, peneliti ingin menjelaskan tentang gambaran pembiasaan spiritual yang telah diterapkan oleh SD Negeri 3 Cicurug untuk meningkatkan pembentukan karakter pada peserta didik.

\section{Data, Instrumen, dan Teknik Pengumpulan Data}

Penelitian yang baik tentu memerlukan informasi dan data yang akurat, sehingga untuk penelitian ini peneliti menggunakan beberapa metode penelitian untuk menggali informasi dan data tersebut. Adapun beberapa metode yang digunakan peneliti sebagai berikut:

\section{Metode Observasi}

Observasi dilakukan jika yang diteliti berupa perilaku manusia, gejala-gejala alam dan proses kerja. Dan biasanya, responden yang diamati tidak terlalu banyak.(Albi Anggito, 2018). Tujuan dari observasi adalah untuk mendeskripsikan lingkungan (site) yang diamati, aktivitas-aktivitas yang berlangsung, orang-orang yang dilibatkan dalam proses aktivitas dilingkungan tersebut maka akan nampak perilakuperilaku yang dimunculkan sesuai dengan kejadian berdasarkan pemikiran seseorang yang dilibatkan. Peneliti menggunakan metode observasi untuk mendapatkan informasi tentang pembiasaan spiritual dalam pendidikan karakter pada peserta didik di SD Negeri 3 Cicurug dengan menuju lapangan, mengamati proses pelaksanaan dalam pembiasaan kegiatan religius, dan peneliti juga melakukan pencatatan informasi dikaitkan dengan konteks penelitian.

\section{Metode Wawancara}

Wawancara merupakan suatu cara untuk mendapatkan dan mengumpulkan informasi dengan dilaksanakannya proses tanya jawab secara lisan, harus secara langsung bertatap muka dengan target/subyek yang telah ditentukan. Hadari dalam Luthfiyah (2018) menyatakan, wawancara dilakukan untuk mendapatkan sebuah pemahaman yang holistik atas cara pandang seseorang terhadap suatu topik tertentu. Untuk memperoleh informasi dalam penelitian ini selain metode observasi, peneliti juga menggunakan metode wawancara. Yang nantinya wawancara dilakukan dengan narasumber, diantaranya kepala sekolah, guru, dan peserta didik.

\section{Metode Dokumentasi}

Dokumen terkait orang ataupun sekelompok orang, rentetan peristiwa yang telah terjadi, terkait dalam situasi sosial yang berhubungan dengan fokus penelitian merupakan sumber informasi yang penting dalam penelitian kualitatif (Yusuf, 2016). Peneliti menggunakan metode dokumentasi untuk melengkapi penggunaan metode observasi dan mengambil data-data terkait profil sekolah, program kepeserta didikan sekolah, dan absensi peserta didik dalam beberapa kegiatan spiritual. 


\section{Teknik Analisis Data}

\section{Reduksi Data}

Mereduksi data berarti memilih beberapa informasi yang pentingnya saja. Sehingga dari data yang didapatkan dalam penelitian pembiasaan spiritual dalam pendidikan karakter pada peserta didik nantinya peneliti melakukan pemilihan hal-hal yang perlu dan akan membuang hal-hal yang tidak dibutuhkan.

\section{Penyajian Data}

Setelah direduksi, maka hal yang perlu dilakukan adalah menyajikan (display) data, hal ini dilakukan untuk dapat memudahkan kita untuk mengerti tentang apa yang akan dirancang atau apa yang akan direncanakan selanjutnya berdasarkan data yang ada. Peneliti menggunakan penyajian data yaitu untuk menyajikan data yang telah diperoleh. Adapun data atau informasi yang didapatkan berupa hasil observasi, wawancara, dan dokumentasi, yang nantinya dibaca, dipelajari dan dikaji serta di analisis dengan teliti.

\section{Penarikan Kesimpulan atau Verifikasi}

Bagian yang paling penting dalam teknik analisis data adalah penarikan kesimpulan atau bisa juga disebut dengan verifikasi (Yusuf, 2016). Kesimpulan merupakan metode yang digunakan peneliti dalam menarik kesimpulan dari berbagai informasi yang diperoleh dari narasumber di SD Negeri 3 Cicurug kecamatan Cicurug kabupaten Sukabumi. Sehingga nantinya dapat diketahui kesimpulan penelitian yang dilakukan peneliti, melalui hasil observasi, wawancara, dan dokumentasi yang diperoleh.

\section{HASIL DAN PEMBAHASAN}

Pendidikan karakter bertujuan untuk membentuk sosok pribadi anak/manusia menjadi manusia yang lebih baik bagi diri, keluarga, masyarakat, dan negara. Program pembiasaan spiritual kurang lebih sudah berjalan selama kurang lebih tiga tahun di SD Negeri 3 Cicurug. Kegiatan seperti taushiah, pemberdayaan 3S (Senyum, Sapa dan Salam), pembacaan/hafalan surat-surat pendek, pembacaan do'a sebelum kegiatan belajar mengajar, pelaksanaan sholat Dzuhur berjamaah, penjadwalan sholat Dhuha dan pengumpulan infaq (sedekah) pada hari Jum'at.

\section{Taushiah (Pemberian Nasehat)}

Pada pelaksanaan kegiatan taushiah, guru menjadi penceramah secara bergantian sesuai jadwal yang telah ditetapkan. Kegiatan ini diawali dengan kegiatan berdoa bersama, penampilan dari kelas yang telah dijadwalkan, setelah itu barulah guru memberikan materi taushiahnya. Materi yang disampaikan lebih difokuskan pada pembahasan tentang ilmu Fiqih Muamalah dan rukun-rukun ibadah yang sesuai dengan syariat Islam. Selain itu, pembahasan tentang ketauhidan, diantaranya pemahaman tentang pentingnya mengimani sifat-sifat yang haqq dan bathil pada Allah dan Rasul-Nya serta bagaimana mengimplementasikan kaidah-kaidah keimanan dan ketaqwaan pada kehidupan sehari-hari saat di sekolah maupun di lingkungan sekitar tempat tinggal peserta didik. Dilanjutkan dengan penjelasan tentang akhlak baik dan akhlak buruk terhadap teman sebaya, sopan santun terhadap guru dan orang tua. Kegiatan ini diakhiri dengan pengisian kotak infaq oleh peserta didik dan guru secara sukarela.

Berdasarkan pengamatan dan wawancara yang dilakukan oleh peneliti, 
pelaksanaan program tausiyah ini berdampak terhadap meningkatnya kecerdasan emosional dan tingkat kreatifitas peserta didik. Sebelum diadakannya program tausiyah ini, tidak lebih dari 25\% peserta didik yang mampu menerapkan sikap terpuji, seperti masih maraknya peserta didik yang menggunakan bahasa kasar dalam komunikasi dengan teman, pemahaman mengenai hal agama yang masih minim dan tingkat partisipasi peserta didik pada kegiatan keagamaan di sekolah ini masih rendah. Setelah berjalannya program tausiyah di SDN 3 Cicurug, kini lebih dari 50\% peserta didik telah mampu mengaplikasikan dengan baik pesan moral dan nilai-nilai akhlak mulia yang disampaikan pemateri, sehingga dapat dikatakan bahwa kegiatan taushiah ini memberikan dampak yang cukup positif terhadap perkembangan pendidikan karakter peserta didik di SDN 3 Cicurug.

\section{Pemberdayaan 3S (Senyum, Sapa, Salam)}

Pemberdayaan serta pembiasaan kegiatan 3S (Senyum, Sapa, Salam) juga dilaksanakan pada kegiatan sehari hari. Pembiasaan 3S ini dimaksudkan untuk memberikan pengajaran kepada peserta didik tentang pentingnya menjaga hubungan silaturrahim dan menjalin kekerabatan sebagai sebuah keluarga dengan guru, karyawan maupun teman melalui senyum, saling bertegur sapa dan mengucapkan salam untuk mendoakan kebaikan terhadap sesame, yang nilainya juga setara dengan ibadah-ibadah yang lainnya. Dengan pembiasaan ini, peserta didik diharapkan dapat merasakan kasih sayang yang sama di sekolah sebagaimana yang ia dapatkan dari orang tua dan keluarganya dirumah. Pembiasaan 3S inipun disambut baik oleh para guru dengan memberikan keteladanan pada peserta didik, dimulai dengan penyambutan peserta didik oleh guru didepan pintu gerbang sekolah setiap pagi untuk menyambut kedatangan peserta didik, sehingga peserta didik merasakan bahwa kehadirannya di sekolah dirindu oleh para guru dan temantemannya. Setiap bertemu guru, peserta didik selalu bersalaman guna mengaplikasikan sikap hormat terhadap guru. Pembiasaan seperti ini tidak hanya berlaku untuk peserta didik namun juga untuk guru serta karyawan di sekolah.

Sebelum direalisasikan program $3 \mathrm{~S}$ di SDN 3 Cicurug, lingkungan dan suasana pembelajaran di sekolah cenderung tidak terlalu kondusif. Banyak guru yang tidak mengenal baik peserta didik, begitupun sebaliknya. Guru dan peserta didik datang lambat ke sekolah sehingga proses pembelajaran tertunda, ditemukan beberapa masalah yang disebabkan oleh miskomunikasi, baik antara sesama guru, guru dan peserta didik, maupun antara peserta diik itu sendiri. Namun setelah dicanangkan program 3S ini, baik guru maupun peserta didik, memiliki jalinan komunikasi yang lebih baik dan dapat mengembangkan sikap disiplin, tepat waktu, saling menghormati dan menghargai antara satu dengan yang lain.

\section{Pembacaan Do'a Sebelum Memulai Pembelajaran}

Sudah merupakan kewajiban bagi guru di SD Negeri 3 Cicurug ini untuk mengajak peserta didik secara bersama-sama membaca doa sebelum memulai proses kegiatan belajar mengajar. Bahkan ada beberapa kelas yang membaca doa dan dilanjutkan dengan marhaba (sholawat dan pujian untuk Rasulullah SAW) dahulu sebelum memulai pembelajaran. Hal ini menjadikan nilai lebih bagi sekolah, karena dengan program tersebut peserta didik 
sudah diperkenalkan dan sudah dibiasakan sedini mungkin untuk melaksanakan perintah Allah serta kebaikan-kebaikan yang sudah seharusnya tertanam di setiap hati manusia. Pembacaan doa ini secara langsung telah berpengaruh pada sikap disiplin dan pemahaman spiritual anak. Dengan pembacaan doa sebelum pembelajaran dilaksanakan, anak meyakini bahwa setiap tindak tanduk, sikap, perilaku, dan apa yang terlintas di pikirannya akan diawasi oleh Allah SWT. Dengan demikian, anak akan lebih disiplin dan lebih dapat diarahkan oleh guru selama proses pengajaran berlangsung. Karena secara psikologis, peserta didik sudah merasa tenang dan siap melakukan pembelajaran (menuntut ilmu).

\section{Pembacaan Surat-surat Pendek}

Pembiasaan spiritual lainnya adalah pembacaan surat surat pendek yang dilakukan setiap mengawali proses kegiatan belajar mengajar, dan dilaksanakan secara rutin setiap hari dengan dipimpin oleh guru tahfidz (tutor khusus) didampingi oleh guru kelas masing-masing.

Salah satu dampak positif dari kegiatan ini diantaranya, SDN 3 Cicurug telah beberapa kali mendelegasikan perwakilan peserta didiknya untuk kegiatan lomba Musabaqoh Tilawatil Qur'an (MTQ) ke berbagai perlombaan. Dari hasil wawancara dan dokumentasi berupa catatan perkembangan prestasi peserta didik, diketahui ada sebesar $12 \%$ atau rata-rata 3 peserta didik dari setiap kelas telah mampu untuk menghafal 20 surat pendek Al-quran juz 30. Pencapaian ini tentunya masih harus ditingkatkan, sehingga upaya-upaya pendampingan secara khusus juga terus diberikan bagi peserta didik yang masih rendah tingkat pencapaian hafalannya.
Dalam kegiatan ini, sekolah juga bekerjasama dengan orang tua, sehingga pembiasaan menghafal al-Qur'an yang telah didapatkan di sekolah juga dapat dilakukan dan dilancarkan kembali dirumah dibawah arahan dan pengawasan orang tua. Lebih jauh, kegiatan ini juga mendapat tanggapan yang sangat positif dari orang tua wali murid khususnya, karena kegiatan positif seperti ini dapat lebih memotivasi anak untuk cepat menghafal dan mencintai alQur'an dan memahami maknanya sebagai bagian dari ibadah. Dengan pembiasaan membaca al-Qur'an di sekolah, peserta didik diharapkan dapat lebih meningkatkan keimanan dan ketaqwaannya agar dapat menjadi anak dengan pribadi yang lebih baik dan tidak mudah terbawa lingkungan yang sudah teralihkan oleh globalisasi, serta mampu melawan arus negatif secara seimbang.

Selanjutnya, pada setiap tengah semester akan dilakukan evaluasi bersama bagian kepeserta didikan dan para guru terkait pencapaian hafalan surat-surat pendek yang sudah dilaksanakan untuk dapat disusun rencana tindak lanjut yang diperlukan bagi peningkatan pencapaian target daripada kegiatan ini.

\section{Shalat Dzuhur Berjamaah}

Sekolah memberlakukan kebijakan bahwa setiap kali Tarhim atau sholawat sebelum adzan berkumandang maka segala aktifitas di kelas harus sudah diberhentikan seketika. Maka guru menyerukan seluruh peserta didiknya untuk segera pergi ke mesjid untuk melakukan sholat Dzuhur berjamaah. Kebijakan ini juga berlaku untuk semua tenaga pendidik di SDN 3 Cicurug baik guru maupun staffnya. Tujuan didakannya program sholat Dzuhur berjamaah ini ialah memupuk kesadaran bahwa panggilan Allah harus disegerakan, menambah sikap disiplin 
kepada setiap manusia serta menambah tingkat spiritual dan kedekatan manusia dengan Sang Pencipta.

Karena dengan terbiasa melaksanakan sholat di awal waktu, diharapkan peserta didik juga akan membiasakan diri untuk selalu berdisiplin, bukan hanya dalam melaksanakan ibadah sholat, namun juga dalam pelaksanaan kegiatan dan aktifitas lain di sekolah dan di rumah. Sehingga berdampak baik terhadap penanaman karakter peserta didik untuk mentaati peraturan atau komitmen komitmen yang telah dibangun di sekolah dengan kesadaran peserta didik sendiri.

\section{Sholat Dhuha dan Infaq}

Sholat Dhuha berjamah dilaksanakan setiap Jumat pagi di halaman sekolah dan dilaksanakan sebelum melaksanakan kegiatan belajar mengajar di kelas pada hari yang sama dilanjutkan dengan infaq. Jumlah infaq yang dikeluarkan bersifat seikhlasnya, sesuai kemampuan masing masing peserta didik. Penanaman sifat peduli dan dermawan merupakan tujuan khusus dari kegiatan infaq. Begitu juga dengan sholat Dhuha, dengan membiasakan diri melaksanakan sholat Dhuha, peserta didik diharapkan untuk mempunyai karakter syukur dan tidak mudah kufur terhadap nikmat-nikmat yang Allah SWT berikan dalam kehidupan.

Dari pembahasan diatas dapat dilihat bahwa upaya yang dilaksanakan guna meningkatkan pemahaman serta mutu/kualitas pendidikan berkarakter di SDN 3 Cicurug telah dilaksanakan melalui beberapa kegiatan yang berorientasi pada peningkatan spiritualitas dan pembentukan karakter peserta didik. Sehingga diharapkan, sekolah sebagai institusi pendidikan dasar dapat mencetak generasigenerasi yang bukan hanya cerdas secara intelektual, namun juga memiliki kecerdasan emosional, sosial, dan kecerdasan spiritual yang baik, sehingga kelak dapat berkontribusi positif terhadap agama, bangsa dan negaranya.

Beberapa nilai yang terlihat dari hasil kegiatan pembiasaan spiritual ini yaitu sikap terpuji, baik dalam perilaku maupun perkataan, sikap religius, jujur, mandiri, bertanggungjawab, disiplin, toleransi, cinta damai dan peduli sosial. Dengan demikian, dapat dikatakan bahwa pendidikan karakter yang dicanangkan sebagai salah satu program unggulan di SDN 3 Cicurug telah memenuhi kriteria peningkatan mutu pendidikan karakter karena pendidikan tidak hanya mencakup hal kognitif dan pengetahuan saja, melainkan juga pembiasaan yang baik dan konsep spiritual yang diaplikasikan dalam kehidupan sehariharinya.

\section{KESIMPULAN DAN IMPLIKASI}

\section{Kesimpulan}

Hasil penelitian ini merujuk pada beberapa simpulan, yaitu: 1) pembiasaan spiritual di SD Negeri 3 Cicurug dilaksanakan melalui serangkaian program yang terintegrasi dalam proses pembelajaran peserta didik, 2) dengan metode pembiasaan, peserta didik melaksanakan seluruh kegiatan keagamaan dengan rasa sukarela tanpa keterpaksaan, 3) pembiasaan spiritual merupakan pembelajaran secara langsung (experientiallearning), karena peserta didik diarahkan untuk mengalami langsung aktifitas tersebut untuk kemudian dapat mengambil ilmu dan nilai dari pengalaman tersebut, 4) metode pembiasaan terbukti menjadi metode yang paling efektif dibandingkan beberapa metode lain dalam mengajarkan nilai-nilai keagamaan kepada peserta didik, 
5) pembiasaan spiritual dapat meningkatkan kesadaran peserta didik dan guru dalam mengembangkan sikap terpuji, religius, jujur, mandiri, bertanggungjawab, disiplin, toleransi, cinta damai dan peduli sosial.

\section{Implikasi}

Implikasi dari penilitian ini yakni peran pembiasaan spiritual di SDN 3 Cicurug memberikan dampak yang baik dalam peningkatan mutu terhadap pendidikan karakter peserta didik di SDN 3 Cicurug dalam kehidupan sehari-hari. Programprogram spiritual di sekolah juga lebih variatif dan dilakukan secara intensif sebagai upaya peningkatan akhlak dan karakter itu sendiri. Kondisi seperti ini juga dapat menciptakan lingkungan yang nyaman, ramah, religius dan menyenangkan bagi peserta didik.

Program pembiasaan spiritual juga dapat berjalan seiring dengan program unggulan pemerintah dalam penguatan pendidikan karakter yang terintegrasi dalam beberapa aspek pembelajaran di kurikulum 2013, yaitu aspek kognitif, afektif dan psikomotorik.

\section{DAFTAR PUSTAKA}

'Ulwan, A. N. (2012). Pendidikan anak dalam Islam. Penerbit Insan Kamil Solo.

Aeni, A. N. (2016). PENDIDIKAN KARAKTER UNTUK SISWA SD DALAM PERSPEKTIF ISLAM. Mimbar Sekolah Dasar. https://doi.org/10.17509/mimbarsd.v1i1.863

Ainiyah, N. (2013). PEMBENTUKAN KARAKTER MELALUI PENDIDIKAN AGAMA ISLAM, 13(1), 25-38.

Albi Anggito, J. S. (2018). Metodologi penelitian kualitatif.
Benninga, J. S., \& Berkowitz, M. W. (2017). Journal of Character Education Issue: Vol. 13 \#1. Information Age Publishing.

Depiyanti, O. M. (2014). MODEL PENDIDIKAN KARAKTER DI ISLAMIC FULL DAY SCHOOL (Studi Deskriptif pada SD Cendekia Leadership School, Bandung). TARBAWY : Indonesian Journal of Islamic Education, 1(2), 132-141.

Kadek, O., Herawan, D., Pgri Denpasar, S., Nilai, R., Karakter, P., Suddhamala, G., ... Ketut Sudarsana, I. (2017). RELEVANSI NILAI PENDIDIKAN KARAKTER DALAM GEGURITAN SUDDHAMALA UNTUK MENINGKATKAN MUTU PENDIDIKAN DI INDONESIA, 3(2), 223-236.

Khotimah, K., \& Manajemen Pendidikan Karakter, M. (2016). MODEL MANAJEMEN PENDIDIKAN KARAKTER RELIGIUS DI SDIT QURROTA A'YUN PONOROGO. Muslim Heritage, 1(2), 371387.

Luthfiyah, M. F. (2018). Metodologi penelitian: penelitian kualitatif, tindakan kelas \& studi kasus.

Mumpuni, A. (2018). Integrasi Nilai Karakter dalam Buku Pelajaran: Analisis Konten Buku Teks Kurikulum 2013.

Muslich, M. (2011). Pendidikan karakter: menjawab tantangan krisis multidimensional. Bumi Aksara.

Nucci, L., Narvaez, D., \& Krettenauer, T. (2014). Handbook of Moral and Character Education. Taylor \& Francis.

Patmonodewo, S., \& Kebudayaan, D. P. \&. (2000). Pendidikan anak prasekolah. Rineka Cipta bekerjasama dengan Departemen Pendidikan \& Kebudayaan.

Prof. Dr. A. Muri Yusuf, M. P. (2016). Metode Penelitian Kuantitatif, Kualitatif \& Penelitian Gabungan.

Rahmawati, U., \& Tengah, J. (2016). Pengembangan Kecerdasan Spiritual santri: Studi terhadap Kegiatan 
Keagamaan di Rumah TahfizQu Deresan Putri Yogyakarta. Jurnal Penelitian, 10(1), 97-124.

Rukajat, A. (2018). Pendekatan Penelitian Kualitatif (Qualitative Research Approach).
Sukardi, I. (2016). Character Education Based on Religious Values: an Islamic Perspective. Ta'dib: Jurnal of Islamic Education.

Zaini, A. H. F., Romli, L., \& Winarno, Y. P. (2013). Pilar-pilar pendidikan karakter islami. Gunung Djati Press. 